\title{
ANALISIS PERENCANAAN JARINGAN LTE PICOCELL DI STADION UTAMA GELORA BUNG KARNO
}

\author{
Fajar Adityawarman ${ }^{1}$, Arfianto Fahmi ${ }^{2}$, Uke Kurniawan Usman ${ }^{3}$ \\ 1, 2, ${ }^{3}$ Fakultas Teknik Elektro, Universitas Telkom

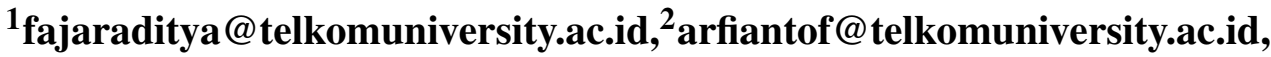 \\ 3 usman.uke@telkomuniversity.ac.id
}

\begin{abstract}
Abstrak
Stadion Utama Gelora Bung Karno (SUGBK) adalah sebuah stadion serbaguna yang berstandar internasional dan sering dijadikan sebagai tempat untuk pertandingan olahraga nasional maupun internasional. Dengan kapasitas penonton yang banyak dan struktur bangunan yang menghalangi propagasi sinyal dari site outdoor menyebabkan kualitas sinyal sangat buruk sehingga perlu adanya perencanaan jaringan dari sisi kapasitas dan juga cakupan di dalam bangunan agar pelanggan tetap mendapatkan layanan yang baik dari kemampuan teknologi yang ada saat ini. Pada hasil perencanaan didapatkan nilai Reference Signal Received Power (RSRP) untuk keseluruhan area pada skenario 1 yaitu sebesar $\mathbf{- 7 4 , 1 0} \mathrm{dBm}$ dan skenario 2 yaitu sebesar $\mathbf{- 7 4 , 0 8} \mathrm{dBm}$. Pada hasil perencanaan didapatkan nilai Signal to Interference Ratio (SIR) untuk keseluruhan area pada skenario 1 yaitu sebesar 19,04 dB dan skenario 2 yaitu sebesar 21,49 dB. Berdasarkan Key Performance Indicator (KPI) operator acuan yaitu untuk parameter RSRP harus $>-90 \mathrm{dBm}(90 \%$ area) dan parameter SIR harus $>0$ dB (90\% area) maka hasil prediksi disimulasi nilai RSRP \& SIR skenario 1 dan 2 mencapai target KPI.
\end{abstract}

Kata Kunci: LTE, Coverage Planning, Capacity Planning

\section{Abstract}

Gelora Bung Karno Main Stadium (SUGBK) is an international standard multipurpose stadium and is often used as a venue for national and international sporting events. With large viewer capacity and building structures that obstruct signal propagation from outdoor sites causing poor signal quality so there is a need for network planning in terms of capacity and coverage within the building to keep customers in good service from current technological capabilities. From planning result, it was obtaining which got value of Reference Signal Received Power (RSRP) for entire area in scenario 1 equal to $\mathbf{- 7 4 , 1 0} \mathrm{dBm}$ and scenario 2 equal to $\mathbf{- 7 4 , 0 8} \mathbf{d B m}$. Meanwhile, it was obtaining got value of Signal to Interference Ratio (SIR) for entire area in scenario 1 equal to 19,04 dB and scenario 2 equal to 21,49 dB. Based on the Key Performance Indicator (KPI) the reference operator is for RSRP parameters should be $>-90 \mathrm{dBm}(90 \%$ area) and SIR parameters should be $>0 \mathrm{~dB}(90 \%$ area) then the predicted result is simulated RSRP \& SIR value scenarios 1 and 2 reach the target KPI.

Key Words: LTE, Coverage Planning, Capacity Planning

\section{Pendahuluan}

Semakin meningkatnya kebutuhan terhadap komunikasi data membuat para operator berlomba untuk memberikan kualitas layanan yang terbaik untuk user dan memberikan kualitas layanan yang baik di dalam sebuah bangunan atau indoor merupakan sebuah tantangan dikarenakan terdapat obstacle yang harus dilewati sinyal yang dipancarkan. Pada bangunan yang struktur bangunannya dapat meredam sinyal dan di dalamnya memiliki kapasitas yang sangat besar juga sering digunakan untuk berbagai macam acara, seperti stadion. Stadion Utama Gelora Bung Karno merupakan salah satu contoh stadion yang dapat dianalisa mengenai permasalahan kualitas sinyal yang kurang baik. Stadion yang memiliki ukuran lapangan 105 x $70 \mathrm{~m}$ dan berkapasitas 78.000 penonton ini juga merupakan stadion yang disediakan oleh pemerintah pusat untuk pertandingan sepak bola tingkat internasional [1]. Ketika ada pertandingan sepak bola, banyak user di dalam stadion yang menggunakan layanan data seperti mengunduh atau mengunggah video dan gambar, atau sekedar chatting.

Pada Gambar 1 dapat dilihat hasil walktest atau pengujian level sinyal menggunakan aplikasi GNetTrackLite. Yang menununjukan bahwa level sinyal di dalam bangunan tersebut sangat buruk karena nilai 


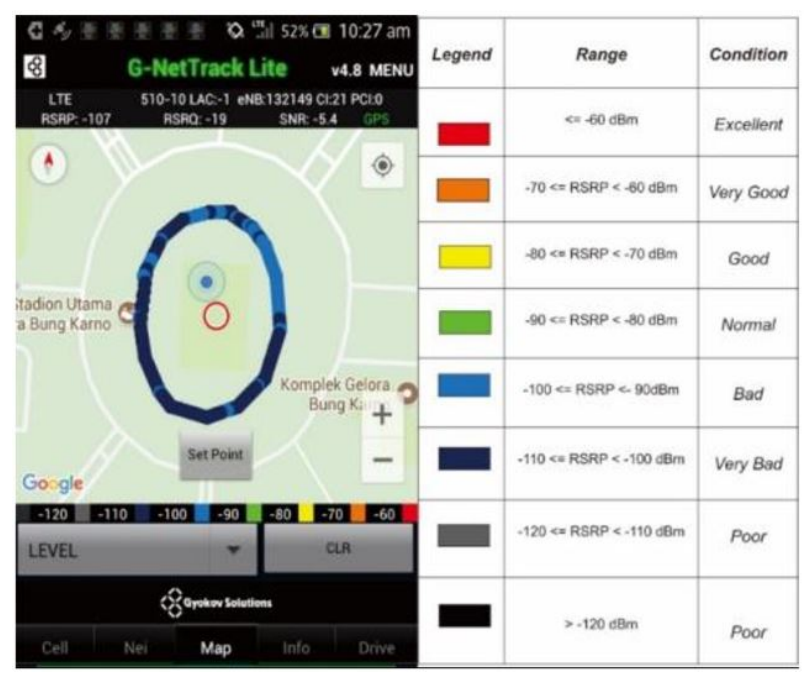

Gambar 1. Hasil Walktest

RSRP berada pada rentang $-90 \mathrm{dBm}$ hingga $-110 \mathrm{dBm}$.

Supaya user di dalam Stadion Utama Gelora Bung Karno dapat terlayani dengan baik oleh jaringan, maka perlu dilakukan perencanaan jaringan LTE dengan pendekatan capacity planning dan coverage planning untuk mendapatkan jumlah cell yang dibutuhkan. Pada penelitian ini ukuran sel yang digunakan adalah picocell karena radiusnya cukup besar dan cocok untuk di aplikasikan pada bangunan ini. Jumlah picocell yang didapat, akan disimulasikan dengan software Radiowave Propagation Simulator (RPS). Parameter yang digunakan dalam perencanaan ini adalah nilai RSRP dan SIR.

\section{Dasar Teori}

\subsection{Long Term Evolution}

Long Term Evolution (LTE) adalah salah satu teknologi yang dikeluarkan oleh badan standarisasi 3GPP (Third Generation Partnership Project) yang merupakan generasi teknologi ke-4 (4G). Teknologi LTE merupakan pengembangan dari teknologi yang dikeluarkan badan standarisasi 3GPP sebelumnya yaitu teknologi 3G atau yang dikenal sebagai Universal Mobile Telecommunication System (UMTS), dan merupakan pengembangan dari teknologi $2 \mathrm{G}$ atau Global System for Mobile Communication (GSM). Untuk melanjutkan pengembangan dari teknologi GSM dan UMTS, teknologi LTE dibuat dengan asumsi semua layanan akan berbasis Internet Protocol (IP), tidak menggunakan layanan berbasis circuit switch seperti teknologi sebelumnya.

LTE dilatar belakangi karena perlu adanya teknologi yang lebih baik dari teknologi sebelumnya yaitu UMTS $(3 \mathrm{G})$, permintaan untuk transfer data rate yang lebih tinggi, membuat jaringan berbasis paket, membuat arsitektur yang lebih sederhana hingga mengurangi biaya CAPEX dan OPEX. Teknologi ini mampu memberikan kecepatan akses data hingga 50 Mbps untuk uplink dan 100 Mbps untuk downlink. Bandwidth yang digunakan pada LTE adalah fleksibel karena bisa menggunakan bandwidth 1.4, 3, 5, 10, 15, dan $20 \mathrm{MHz}$. LTE juga menyediakan layanan multimedia seperti voice, video, data, dan IP TV [2].

\subsection{Perencanaan In Building Network}

Perencanaan In Building Network adalah suatu perencanaan jaringan menggunakan perangkat transceiver yang diletakkan di dalam bangunan yang berfungsi untuk melayani kebutuhan jaringan telekomunikasi dalam bangunan tersebut baik kualitas sinyal, cakupan sinyal atau kapasitas trafiknya.

Target perencanaan yang dilakukan adalah untuk mencapai desain Radio Network yang tepat sesuai dengan QoS, kapasitas, biaya, penggunaan frekuensi, service coverage, equipment deployment dan performance [3].

\subsection{Picocell}

Picocell adalah sebuah wireless base station dengan daya yang sangat kecil yang dibuat untuk mencakup daerah yang sangat kecil, seperti satu lantai sebuah bangunan. Dalam jaringan seluler, picocell biasa digunakan untuk menambah jangkauan ke area indoor apabila sinyal dari base station yang berada di area outdoor tidak tersampaikan, atau tujuan lainnya adalah menambah kapasitas jaringan pada area yang penggunaan jaringan selulernya sangat tinggi atau terbilang padat, seperti stasiun kereta, pesawat, dan pusat perbelanjaan.

Dengan menggunakan tipe sel picocell akan didapatkan beberapa keuntungan bagi pengguna seperti berikut [4]

1. Picocell memberikan solusi kepada bangunan indoor yang memiliki coverage sinyal yang buruk karena struktur bangunannya yang meredam sinyal.

2. Mengisi blankspot yang ada di area tersebut, biasanya para engineer mengatasi buruknya sinyal dalam bangunan dengan menggunakan repeater. Namun, dapat menggunakan picocell untuk menutupi blankspot tersebut.

3. Menambah kapasitas yang tersedia untuk pelanggan pada suatu area yang memiliki kepadatan jaringan. Menambah sebuah macrocell akan menambah biaya yang dikeluarkan, maka dari itu digunakan picocell dengan daya yang lebih kecil untuk mengurangi biaya.

Tabel 1 menunjukan jenis sel, radius, daya transmisi yang digunakan. 
Tabel 1. Jenis Sel Berdasarkan Ukuran [4]

\begin{tabular}{|c|c|c|}
\hline Tipe Sel & Radius & Rentang Daya \\
\hline Macro & $>1 \mathrm{~km}$ & $20 \mathrm{~W}-160 \mathrm{~W}(40 \mathrm{~W})$ \\
\hline Micro & $250 \mathrm{~m}-1 \mathrm{~km}$ & $2 \mathrm{~W}-20 \mathrm{~W}(5 \mathrm{~W})$ \\
\hline Pico & $100 \mathrm{~m}-300 \mathrm{~m}$ & $250 \mathrm{~mW}->2 \mathrm{~W}$ \\
\hline Femto & $10 \mathrm{~m}-50 \mathrm{~m}$ & $10 \mathrm{~mW}-200 \mathrm{Mw}$ \\
\hline
\end{tabular}

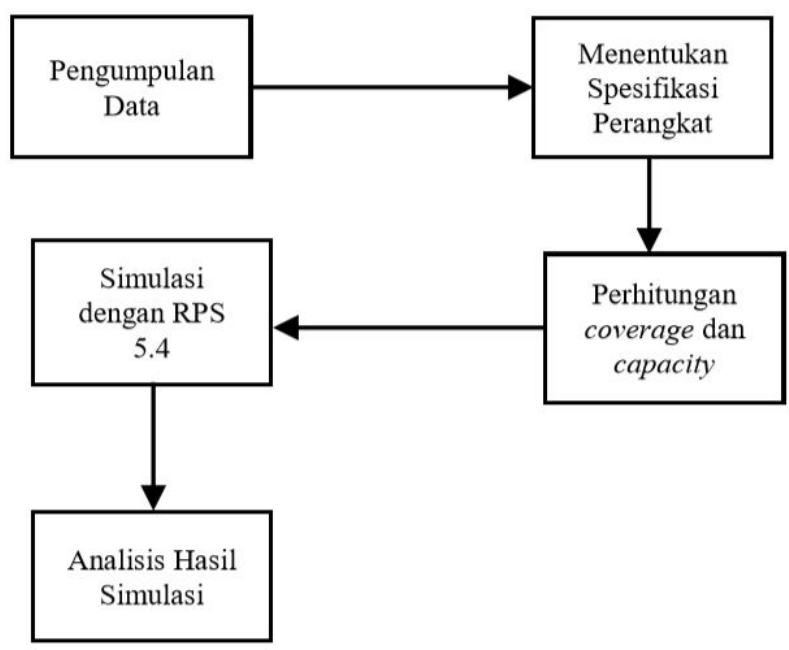

\section{Gambar 2. Blok Diagram Penelitian}

\section{Metodologi Penelitian}

Dalam penelitian ini, ada beberapa langkah yang dilakukan dalam melakukan penelitian simulasi perencanaan jaringan yang dapat dilihat pada Gambar 2 .

\subsection{Capacity Planning}

Capacity planning bertujuan untuk memperkirakan jumlah pelanggan dalam satu sel yang bisa tercakup. Perencanaan ini juga akan menentukan jumlah eNodeB yang diperlukan dengan memperhatikan kualitas layanan yang diberikan kepada user, misalnya throughput. Perencanaan berdasarkan kapasitas ini dilakukan dengan mengestimasi jumlah pelanggan yang akan menggunakan jaringan hasil perencanaan, lalu mengestimasi layanan apa saja yang dapat diakses oleh pelanggan, memperkirakan kepadatan trafik dan kapasitas sel [5]. Hal pertama yang dilakukan adalah mengasumsikan jumlah penonton lalu dikalikan dengan penetrasi LTE pada daerah tersebut. Setelah itu, menghitung layanan dan model trafik menggunakan persamaan (1).

$$
T / S=P S T \times P S D R \times B R \times\left[\frac{1}{1-B L E R}\right],
$$

Keterangan:

$\mathrm{T} / \mathrm{S}=$ Banyak data diterima (Kbit)

PST $=$ Durasi Setiap Layanan (s)

BLER $=$ Toleransi Block Error Rate
Tabel 2. Estimasi Jumlah Sel Capacity Planning

\begin{tabular}{|c|c|l|}
\hline Area & $\begin{array}{c}\text { Jumlah } \\
\text { User }\end{array}$ & $\begin{array}{l}\text { Estimasi } \\
\text { Jumlah } \\
\text { Sel }\end{array}$ \\
\hline Area 1 (Tribun Bawah Barat) & 6297 & 2 \\
\hline Area 2 (Tribun Bawah Timur) & 15074 & 4 \\
\hline Area 3 (Tribun Bawah Utara) & 8007 & 2 \\
\hline Area 4 (Tribun Bawah Selatan) & 14482 & 3 \\
\hline Area 5 (Tribun Atas Barat) & 8255 & 2 \\
\hline Area 6 (Tribun Atas Timur) & 8978 & 2 \\
\hline Area 7 (Tribun Atas Utara) & 8923 & 2 \\
\hline Area 8 (Tribun Atas Selatan) & 8200 & 2 \\
\hline \multicolumn{2}{|c|}{ Jumlah } & 19 \\
\hline \multicolumn{2}{|l|}{} \\
\hline
\end{tabular}

$\mathrm{BR}=$ Application Layer Bit Rate (Kbit)

Dalam perhitungan segi kapasitas juga harus memperhitungkan network throughput dengan menggunakan persamaan (2).

$$
T N T=\frac{T U \times\left(\sum(T / S) \times B H S A \times P R \times(1+P T A R)\right)}{3600},
$$

TNT $=$ Total Network Throughput

$\mathrm{TU}=$ Single User Throughput

$\mathrm{PR}=$ Penetrasi Jaringan Tiap Daerah

PTAR $=$ Peak to Average Ratio

BHSA = Service Attempt in Busy Hour

Langkah selanjutnya adalah menghitung kapasitas suatu site dengan menggunakan persamaan (3).

$D M C+C R C=(168-36-12) \times C B \times C R \times N \times C \times 1000$,

$\mathrm{CRC}=24$

$168=$ jumlah resource element dalam $1 \mathrm{~ms}$

$36=$ jumlah dari kanal control dalam $1 \mathrm{~ms}$

$12=$ jumlah dari reference signal dalam $1 \mathrm{~ms}$

$\mathrm{CB}=$ modulated bits

$\mathrm{CR}=$ channel coding rate

$\mathrm{N}=$ jumlah resource block

$\mathrm{C}=$ MIMO TRX

Untuk menghitung estimasi jumlah sel dari sisi kapasitas menggunakan persamaan (4)

$$
\text { Number of Site }=\frac{\text { Network Troughput }}{\text { Site Capacity }} .
$$

Sesuai dengan perhitungan capacity planning, maka jumlah picocell yang diperlukan di dalam stadion adalah 19 picocell. 
Tabel 3. Perhitungan Uplink Link Budget

\begin{tabular}{|l|c|c|}
\hline Transmitter $(\mathrm{UE})$ & Value & Calculation \\
\hline Max. Tx Power $(\mathrm{dBm})$ & 23 & $\mathrm{~A}$ \\
\hline Tx. Antenna gain $(\mathrm{dBi})$ & 0 & $\mathrm{~B}$ \\
\hline Body Loss $(\mathrm{dB})$ & 3 & $\mathrm{C}$ \\
\hline EIRP & 20 & $\mathrm{D}=\mathrm{A}+\mathrm{B} \mathrm{C}$ \\
\hline Receiver $(\mathrm{BS})$ & Value & Calculation \\
\hline Noise figure $(\mathrm{dB})$ & 4 & $\mathrm{E}$ \\
\hline Thermal noise $(\mathrm{dBm})$ & 104,5 & $\mathrm{~F}=\mathrm{k}$ T BW \\
\hline Receiver Sensitivity $(\mathrm{dBm})$ & 107 & $\mathrm{G}$ \\
\hline Load factor & 0,7 & $\mathrm{H}(70 \%)$ \\
\hline Interference margin $(\mathrm{dB})$ & 2 & $\mathrm{I}$ \\
\hline Rx antenna gain $(\mathrm{dBi})$ & 0 & $\mathrm{~J}$ \\
\hline Cable loss $(\mathrm{dB})$ & 3 & $\mathrm{~K}$ \\
\hline Amplifier gain $(\mathrm{dB})$ & 2 & $\mathrm{~L}$ \\
\hline $\begin{array}{l}\text { Log normal fading margin } \\
\text { (dB) }\end{array}$ & 4 & $\mathrm{M}$ \\
\hline $\begin{array}{l}\text { Maximum Allowed Path } \\
\text { loss } \text { (MAPL) }(\mathrm{dB})\end{array}$ & 120 & $\begin{array}{c}\mathrm{N}=\mathrm{D} \mathrm{G} \mathrm{I+} \\
\text { J K + L M }\end{array}$ \\
\hline
\end{tabular}

\subsection{Coverage Planning}

Coverage planning merupakan perencanaan yang memperhitungkan pathloss arah uplink dan downlink untuk mendapatkan besarnya cakupan/cell radius. Setelah mendapatkan cell radius, maka bisa didapatkan jumlah picocell yang dibutuhkan agar seluruh area dalam bangunan tersebut bisa tercakup [6]. Tabel 3

Untuk link budget arah downlink dapat dilihat pada

Dalam perencanaan LTE indoor ini menggunakan frekuensi $1800 \mathrm{MHz}$, dan digunakan pemodelan propagasi Cost-231 Multiwall untuk mendapatkan nilai radius cell dengan menggunakan persamaan (5) [8].

$$
L=L_{S} F+L_{C}+\sum_{i=1}^{I} K w_{i} L w_{i}+k f^{\left(\frac{k f+2}{k f+1}-b\right)} L f n f
$$

Keterangan:

LFS = Free Space Loss

$\mathrm{b}=$ Konstanta Empiris

Lc $=$ Konstanta Loss

$\mathrm{Kw}=$ Jumlah dinding yang dilewati

$\mathrm{Lw}=$ Penetrasi loss dari tipe dinding

$\mathrm{nf}=$ Jumlah lantai yang dilewati

$\mathrm{Lf}=$ Loss per lantai

Dalam perhitungan luas sel pada perencanaan menggunakan sel model bentuk hexagonal dan menggunakan omnidirectional antena. Persamaan luas sel dapat dirumuskan dalam persamaan (6) [9].

$$
L_{s e l}=2,6 \times d^{2},
$$

Tabel 4. Downlink Link Budget [7]

\begin{tabular}{|l|c|c|}
\hline Transmitter & Value & Calculation \\
\hline $\begin{array}{l}\text { Max. Tx Power } \\
(\mathrm{dBm})\end{array}$ & 23 & $\mathrm{~A}$ \\
\hline $\begin{array}{l}\mathrm{Tx} \text { Antenna Gain } \\
(\mathrm{dBi})\end{array}$ & 0 & $\mathrm{~B}$ \\
\hline Cable loss $(\mathrm{dB})$ & 3 & $\mathrm{C}$ \\
\hline EIRP $(\mathrm{dBm})$ & 20 & $\mathrm{D}=\mathrm{A}+\mathrm{B} \mathrm{C}$ \\
\hline Receiver $($ UE) & Value & Calculation \\
\hline UE noise figure $(\mathrm{dB})$ & 7 & $\mathrm{E}$ \\
\hline Thermal noise $(\mathrm{dBm})$ & $-104,5$ & $\mathrm{~F}=\mathrm{k} \mathrm{T} \mathrm{BW}$ \\
\hline $\begin{array}{l}\text { Receiver noise floor } \\
\text { (dBm) }\end{array}$ & $-97,5$ & $\mathrm{G}=\mathrm{E}+\mathrm{F}$ \\
\hline SINR $(\mathrm{dB})$ & -5 & $\mathrm{H}$ \\
\hline $\begin{array}{l}\text { Receiver Sensitivity } \\
\text { (dBm) }\end{array}$ & $-102,5$ & $\mathrm{I}=\mathrm{G}+\mathrm{H}$ \\
\hline Load factor & 0,7 & $\mathrm{~J}(70 \%)$ \\
\hline $\begin{array}{l}\text { Interference margin } \\
(\mathrm{dB})\end{array}$ & 3 & $K=10$ log $\frac{\text { Ij+FBW }}{F B W}$ \\
\hline $\begin{array}{l}\mathrm{Rx} \text { antenna gain } \\
\text { (dB) }\end{array}$ & 0 & $\mathrm{~L}$ \\
\hline Body loss $(\mathrm{dB})$ & 3 & $\mathrm{M}$ \\
\hline $\begin{array}{l}\text { Log normal fading } \\
\text { margin }(\mathrm{dB})\end{array}$ & 4 & $\mathrm{~N}$ \\
\hline $\begin{array}{l}\text { Maximum Allowed } \\
\text { path } \\
\text { loss }(\mathrm{MAPL}) \text { (dB) }\end{array}$ & 112,5 & $\mathrm{O}=\mathrm{D}-\mathrm{I}-\mathrm{K}+$ \\
\hline
\end{tabular}

$L_{\text {sel }}=$ Luas Sel $\left(\mathrm{m}^{2}\right)$

$\mathrm{d}=$ Jari -Jari Sel (m)

Persamaan yang dapat digunakan dalam perhitungan jumlah site berdasarkan hasil coverage planning dapat dilihat pada persamaan (7) [9].

$$
\sum L T E_{\text {sel }}=\frac{\text { Luas Area }}{\text { Luas Sel }}
$$

Sesuai dengan perhitungan coverage planning, maka jumlah picocell yang diperlukan adalah sebanyak 13 picocell.

\section{Hasil Simulasi dan Analisis}

Setelah melakukan perhitungan dari segi coverage planning dan capacity planning didapatkan jumlah sel yang berbeda dari masing -masing perencanaan. Dalam melakukan pemilihan jumlah picocell dalam perencanaan jaringan LTE membutuhkan keseimbangan antara coverage dan capacity. Keseimbangan antara coverage dan capacity yang dimaksud adalah jumlah picocell yang direncanakan harus sesuai atau tercapai tujuan dari coverage planning yaitu semua area yang dilakukan perencanaan dapat tercakup oleh sinyal yang dipancarkan dan juga harus tercapai tujuan dari capacity planning yaitu seluruh user di dalam bangunan harus 
Tabel 5. Estimasi Jumlah Sel Coverage Planning

\begin{tabular}{|c|c|c|c|}
\hline Area & $\begin{array}{c}\text { Luas Area } \\
\left(\mathrm{m}^{2}\right)\end{array}$ & $\begin{array}{c}\text { Luas } \\
\text { Cell }\end{array}$ & $\begin{array}{c}\text { Estimasi } \\
\text { Jumlah } \\
\text { Sel }\end{array}$ \\
\hline $\begin{array}{l}\text { Area } \\
\text { (Tribun } \\
\text { Bawah Barat) }\end{array}$ & 8068,745 & 5063,238 & 2 \\
\hline $\begin{array}{ll}\text { Area } & 2 \\
\text { (Tribun } & \\
\text { Bawah } & \\
\text { Timur) } & \end{array}$ & 8068,745 & 25376,302 & 1 \\
\hline $\begin{array}{l}\text { Area } \\
\text { (Tribun } \\
\text { Bawah Utara) }\end{array}$ & 8068,745 & 259673,92 & 1 \\
\hline $\begin{array}{ll}\text { Area } & 4 \\
\text { (Tribun } & \\
\text { Bawah } & \\
\text { Selatan) } & \end{array}$ & 8068,745 & 259673,92 & 1 \\
\hline $\begin{array}{lr}\text { Area } & 5 \\
\text { (Tribun } & \text { Atas } \\
\text { Barat) } & \end{array}$ & 5493,593 & 2996,3495 & 2 \\
\hline $\begin{array}{lr}\text { Area } & 6 \\
\text { (Tribun } & \text { Atas } \\
\text { Timur) } & \end{array}$ & 5493,593 & 2996,3495 & 2 \\
\hline $\begin{array}{lr}\text { Area } & 7 \\
\text { (Tribun } & \text { Atas } \\
\text { Utara) } & \end{array}$ & 5493,593 & 2996,3495 & 2 \\
\hline $\begin{array}{lr}\text { Area } & 8 \\
\text { (Tribun } & \text { Atas } \\
\text { Selatan) } & \\
\end{array}$ & 5493,593 & 2996,3495 & 2 \\
\hline
\end{tabular}

mendapatkan throughput yang telah direncanakan sebelumnya. Maka dari itu, pemillihan jumlah picocell yang digunakan pada setiap area adalah jumlah picocell yang terbanyak, yaitu berdasarkan capacity planning.

\subsection{Simulasi RSRP Berdasarkan Skenario 1}

Pada saat akan melakukan simulasi pada software RPS 5.4 untuk mengetahui performansi hasil perencanaan dari segi parameter Reference Signal Received Power (RSRP), dilakukan dengan cara mengaktifkan antena dan melihat performansi jaringan di seluruh area. Parameter ini merupakan parameter yang dapat mengindikasikan level daya sinyal yang diterima oleh user $(\mathrm{dBm})$. Parameter RSRP ini merupakan hasil kalkulasi daya sinyal dari setiap cell disetiap area, yang digunakan sebagai acuan penentu serving cell user.

Pada skenario 1, penempatan picocell pada tribun bagian bawah ditempatkan secara acak pada dinding bagian tribun bawah pada ketinggian 15 meter, lalu pada tribun bagian atas, picocell diletakkan di dinding dinding pada tribun bagian atas secara menyebar pada ketinggian 30 meter. Hasil simulasi dapat dilihat pada Tabel 6 .
Tabel 6. Hasil Simulasi Skenario 1

\begin{tabular}{|c|c|c|}
\hline Skenario 1 & RSSI $(\mathrm{dBm})$ & RSRP $(\mathrm{dBm})$ \\
\hline $\begin{array}{c}\text { Area 1 (Tribun } \\
\text { Bawah Barat) }\end{array}$ & $-44,05$ & $-74,84$ \\
\hline $\begin{array}{c}\text { Area 2 (Tribun } \\
\text { Bawah Timur) }\end{array}$ & $-40,64$ & $-71,43$ \\
\hline $\begin{array}{c}\text { Area 3 (Tribun } \\
\text { Bawah Utara) }\end{array}$ & $-40,56$ & $-71,35$ \\
\hline $\begin{array}{c}\text { Area 4 (Tribun } \\
\text { Bawah Selatan) }\end{array}$ & $-42,9$ & $-73,69$ \\
\hline $\begin{array}{c}\text { Area 5 (Tribun } \\
\text { Atas Barat) }\end{array}$ & $-44,97$ & $-75,76$ \\
\hline $\begin{array}{c}\text { Area 6 (Tribun } \\
\text { Atas Timur) }\end{array}$ & $-43,92$ & $-74,71$ \\
\hline $\begin{array}{c}\text { Area 7 (Tribun } \\
\text { Atas Utara) }\end{array}$ & $-43,38$ & $-74,17$ \\
\hline $\begin{array}{c}\text { Area 8 (Tribun } \\
\text { Atas Selatan) }\end{array}$ & $-45,26$ & $-76,05$ \\
\hline Semua Area & $-43,31$ & $-74,10$ \\
\hline
\end{tabular}

Dapat dilihat pada Tabel 6 dan Gambar 3 yaitu nilai RSSI keseluruhan area sebesar $-43,41 \mathrm{dBm}$ (RSRP = $74,10 \mathrm{dBm}$ ). Pada Gambar 2 dapat dilihat legend dari masing -masing nilai RSSI pada setiap area.

\subsection{Simulasi RSRP Berdasarkan Skenario 2}

Simulasi pada RPS 5.4 dengan parameter RSRP menggunakan skenario 2 yaitu dimana pada bagian tribun bagian bawah yaitu pada bagian barat dan timur penempatan picocellnya diletakkan di dalam bangunan Royal Box, VIP, dan Corporate Box pada ketinggian 15 meter. Lalu, pada bagian tribun bagian atas penempatan picocellnya diletakkan pada atap - atap stadion bagian tengahnya dengan ketinggian 30 meter dari tanah. Hasil simulasi dengan parameter RSRP berdasarkan skenario 2 dapat dilihat pada Tabel 7

Terlihat pada Tabel 7 dan Gambar 5 yaitu nilai RSSI keseluruhan area sebesar $-43,29 \mathrm{dBm}$ (RSRP = $-74,08 \mathrm{dBm}$ ). Pada Gambar 4 dapat dilihat legend dari masing-masing nilai RSSI pada setiap area.

\subsection{Simulasi SIR Berdasarkan Skenario 1}

Hasil perencanaan jaringan yang telah dilakukan sebelumnya lalu dilakukan simulasi untuk mengetahui performansi jaringan berdasarkan nilai Signal to Interference Ratio (SIR) dilakukan dengan cara mensimulasikan setiap area kemudian mensimulasikan untuk seluruh area secara bersamaan. Nilai parameter SIR adalah merupakan perbandingan antara daya signal terhadap interferensinya dan mengindikasikan kualitas sinyal yang diterima oleh user. Hal-hal yang mempengaruhi nilai parameter SIR adalah jumlah cell yang di dalam gedung oleh karena hal ini dapat meningkatkan terjadinya interferensi. Parameter SIR 

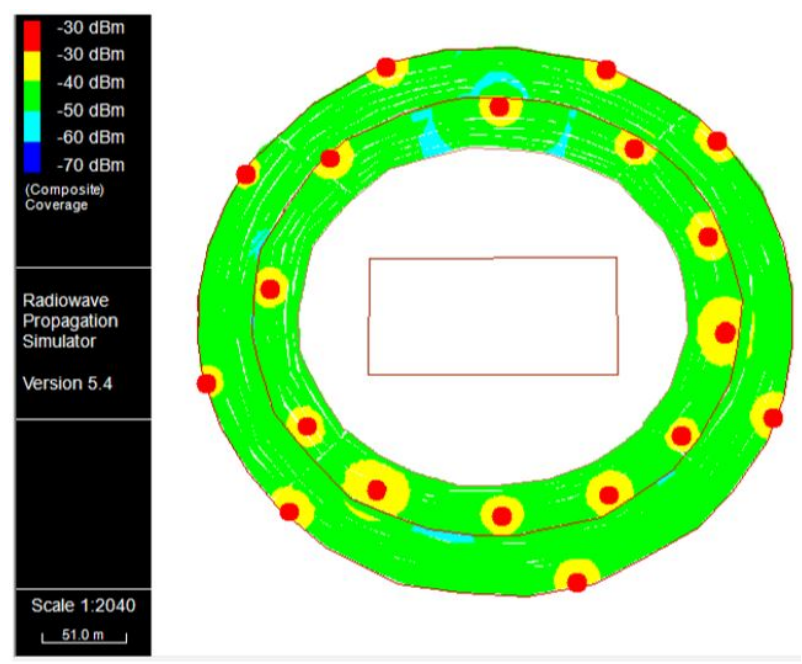

Gambar 3. Simulasi RSSI Skenario 1

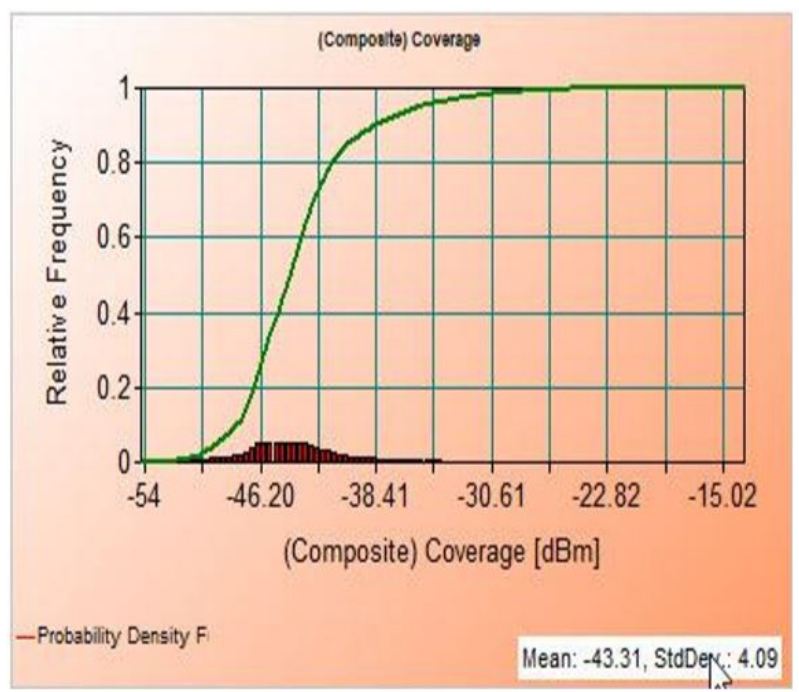

Gambar 4. Histogram RSSI Skenario 1

pada LTE merupakan acuan untuk menentukan jenis modulasi yang digunakan dan mempengaruhi datarate yang dapat diterima user. Hasil simulasi SIR tiap area dengan skenario 1 dapat dilihat pada Tabel 8 .

Pada Tabel 8 dan Gambar 7 menunjukan nilai SIR keseluruhan area sebesar 19,04 dB. Pada Gambar 6 dapat dilihat pada area 1, memiliki legend berwarna biru yang berarti buruk, akibat dari interferensi yang tinggi antara picocell.

\subsection{Simulasi SIR Berdasarkan Skenario 2}

Skema simulasi pada RPS 5.4 untuk mengetahui performansi jaringan berdasarkan nilai Signal to Interference Ratio (SIR) dengan menggunakan skenario 2. Nilai SIR sangat berpengaruh dengan titik penempatan picocell antara satu dengan yang lain karena antara satu picocell dan picocell yang lain memancarkan
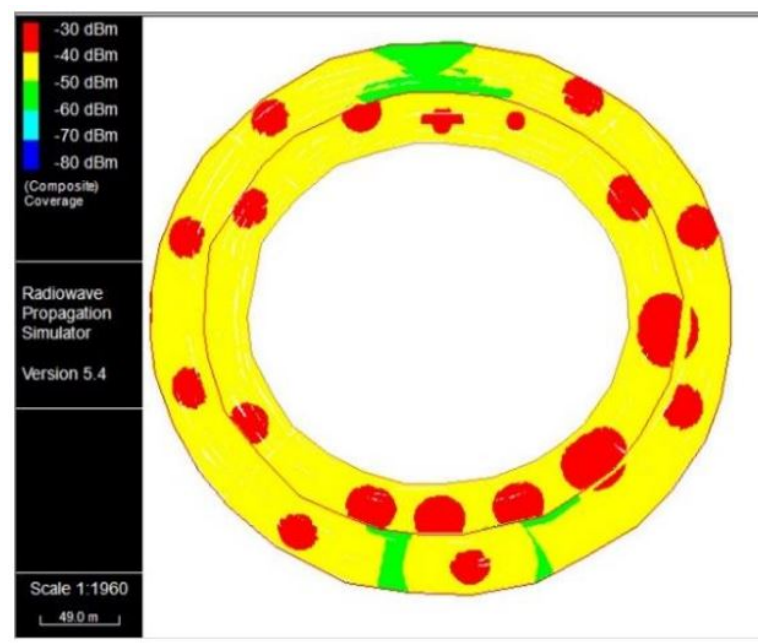

Gambar 5. Simulasi RSSI Skenario 2

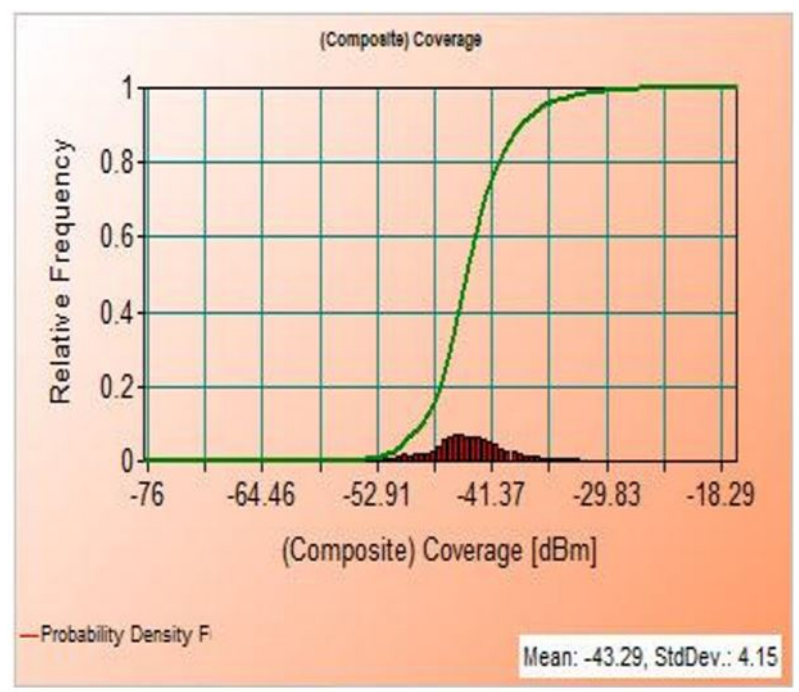

\section{Gambar 6. Histogram RSSI Skenario 2}
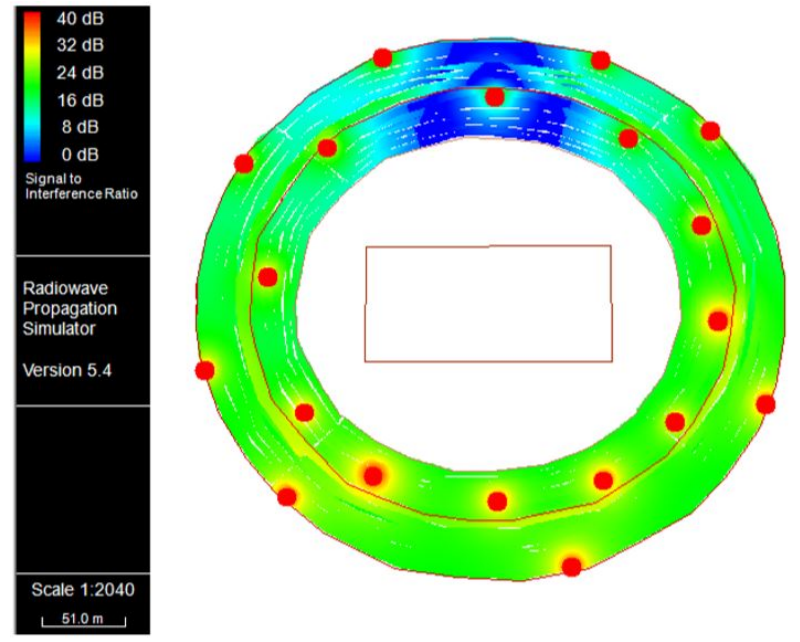

Gambar 7. Simulasi SIR Skenario 1 
Tabel 7. Hasil Simulasi Skenario 2

\begin{tabular}{|c|c|c|}
\hline Skenario 1 & RSSI $(\mathrm{dBm})$ & RSRP $(\mathrm{dBm})$ \\
\hline $\begin{array}{c}\text { Area 1 (Tribun } \\
\text { Bawah Barat) }\end{array}$ & $-43,76$ & $-74,55$ \\
\hline $\begin{array}{c}\text { Area 2 (Tribun } \\
\text { Bawah Timur) }\end{array}$ & $-39,64$ & $-70,43$ \\
\hline $\begin{array}{c}\text { Area 3 (Tribun } \\
\text { Bawah Utara) }\end{array}$ & $-40,75$ & $-71,54$ \\
\hline $\begin{array}{c}\text { Area 4 (Tribun } \\
\text { Bawah Selatan) }\end{array}$ & $-42,98$ & $-73,77$ \\
\hline $\begin{array}{c}\text { Area 5 (Tribun } \\
\text { Atas Barat) }\end{array}$ & $-46,28$ & $-77,07$ \\
\hline $\begin{array}{c}\text { Area 6 (Tribun } \\
\text { Atas Timur) }\end{array}$ & $-45,3$ & $-76,09$ \\
\hline $\begin{array}{c}\text { Area 7 (Tribun } \\
\text { Atas Utara) }\end{array}$ & $-42,57$ & $-74,46$ \\
\hline $\begin{array}{c}\text { Area 8 (Tribun } \\
\text { Atas Selatan) }\end{array}$ & $-43,67$ & $-74,46$ \\
\hline Semua Area & $-43,29$ & $-74,08$ \\
\hline
\end{tabular}

Tabel 8. Hasil Simulasi SIR Skenario 1

\begin{tabular}{|l|l|}
\hline Skenario 1 & SIR $(\mathrm{dB})$ \\
\hline Area 1 (Tribun Bawah Barat) & 7,57 \\
\hline Area 2 (Tribun Bawah Timur) & 24,53 \\
\hline Area 3 (Tribun Bawah Utara & 21,25 \\
\hline Area 4 (Tribun Bawah Selatan) & 19,59 \\
\hline Area 5 (Tribun Atas Barat) & 10,34 \\
\hline Area 6 (Tribun Atas Timur) & 23,41 \\
\hline Area 7 (Tribun Atas Utara) & 21,21 \\
\hline Area 8 (Tribun Atas Selatan) & 20,49 \\
\hline Semua Area & 19,04 \\
\hline
\end{tabular}

daya yang dimana bisa saling menginterferensi satu sama lain dimana interferensinya bisa destruktif maupun konstruktif. Hasil simulasi dengan parameter SIR pada setiap area dan seluruh area berdasarkan skenario 2 dapat dilihat pada Tabel 9.

Hasil simulasi dapat dilihat pada Tabel 9 dan Gambar 9 yaitu nilai SIR keseluruhan area sebesar 21,49 dB. Pada Gambar 8 dapat dilihat area 6 memiliki SIR yang rendah ditandakan legend berwarna biru dan area 2 memiliki SIR yang sangat baik ditandakan dengan legend berwarna merah, hal ini disebabkan tingkat interferensi pada area tersebut kecil karena picocell diletakkan di dalam ruangan.

\subsection{Analisis Berdasarkan KPI}

Perolehan dari simulasi jaringan indoor LTE berdasarkan tinjauan parameter RSRP dan SIR masing-masing rata-rata nilainya dapat dilihat pada Tabel 10.

Maka jika ditinjau dari hasil simulasi dengan acuan KPI untuk parameter RSRP dan SIR berdasarkan

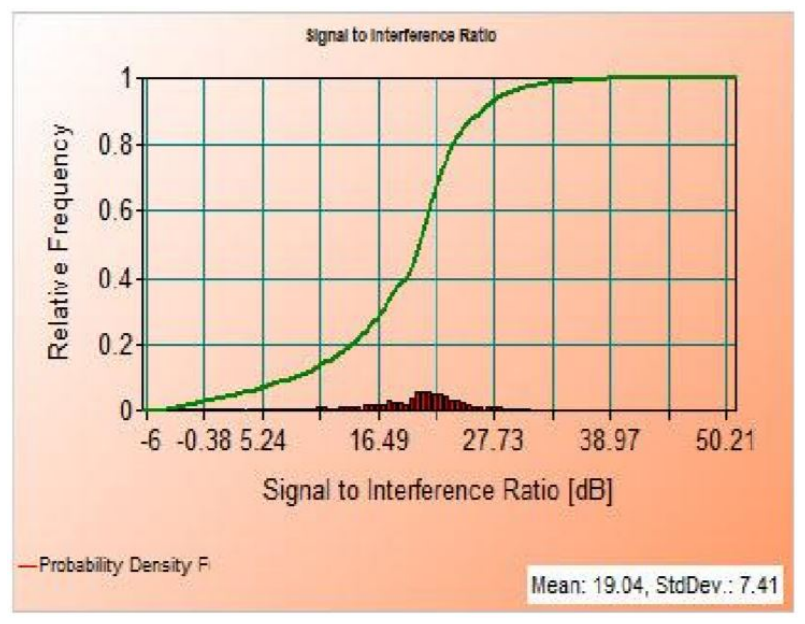

Gambar 8. Histogram SIR Skenario 1

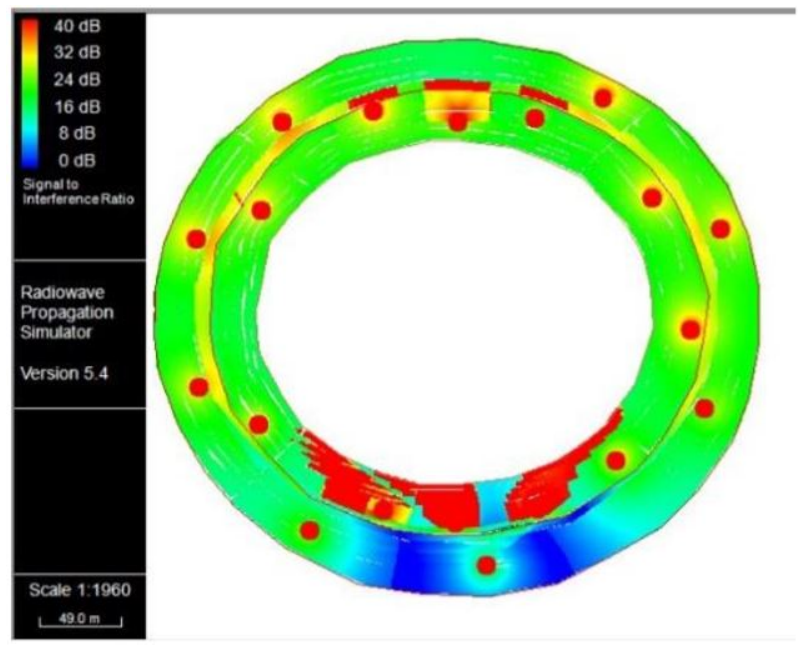

Gambar 9. Simulasi SIR Skenario 2

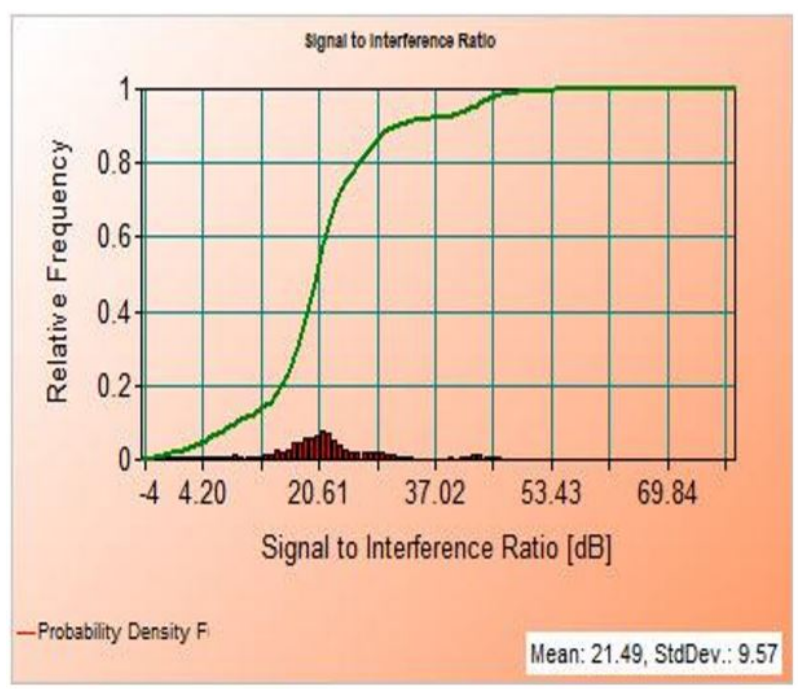

Gambar 10. Histogram SIR Skenario 2 
Tabel 9. Hasil Simulasi SIR Skenario 2.

\begin{tabular}{|l|l|}
\hline Skenario 1 & SIR $(\mathrm{dB})$ \\
\hline Area 1 (Tribun Bawah Barat) & 23,39 \\
\hline Area 2 (Tribun Bawah Timur) & 31,41 \\
\hline Area 3 (Tribun Bawah Utara & 22,69 \\
\hline Area 4 (Tribun Bawah Selatan) & 21,02 \\
\hline Area 5 (Tribun Atas Barat) & 24,18 \\
\hline Area 6 (Tribun Atas Timur) & 9,57 \\
\hline Area 7 (Tribun Atas Utara) & 22,77 \\
\hline Area 8 (Tribun Atas Selatan) & 22,77 \\
\hline Semua Area & 21,49 \\
\hline
\end{tabular}

Tabel 10. Hasil Simulasi Keseluruhan.

\begin{tabular}{|c|c|c|c|c|}
\hline \multirow{2}{*}{ Skenario } & \multirow{2}{*}{$\begin{array}{l}\text { RSRP } \\
(\mathrm{dBm})\end{array}$} & \multirow{2}{*}{$\begin{array}{l}\text { SIR } \\
\text { (dB) }\end{array}$} & \multicolumn{2}{|c|}{ KPI Operator Acuan } \\
\hline & & & $\begin{array}{l}\text { RSRP } \\
(\mathrm{dBm})\end{array}$ & $\begin{array}{l}\text { SIR } \\
(\mathrm{dB})\end{array}$ \\
\hline Skenario 1 & $-74,10$ & 19,04 & $>-90$ & $>0$ \\
\hline Skenario 1 & $-74,08$ & 21,49 & $(90 \%)$ area & $\begin{array}{l}(90 \%) \\
\text { area }\end{array}$ \\
\hline
\end{tabular}

skenario 1 dan 2, perencenaan LTE di Stadion Utama Gelora Bung Karno telah memenuhi persyaratan KPI operator acuan dan layak untuk diimplementasikan. Namun, jika dilihat dari rata rata nilai RSRP dan SIR, skenario 2 memiliki nilai yang lebih baik dan juga seperti yang dapat dilihat sebelumnya pada simulasi SIR dengan skenario 1 , area 1 dimana area tersebut merupakan kawasan untuk tamu VIP, memiliki nilai SIR yang rendah sehingga tidak disarankan. Sehingga, skenario terbaik sesuai dengan simulasi adalah skenario 2 .

\section{Kesimpulan}

Pada penelitian ini bertujuan untuk mendapatkan level sinyal yang baik dengan melakukan perencanaan jaringan di dalam SUGBK. Pada hasil perencanaan didapatkan jumlah picocell yang dibutuhkan untuk area 1,3,5,6,7,8 adalah sebanyak 2 buah dan area 2,4 sebanyak 3 buah. Setelah dilakukan simulasi, didapatkan nilai RSRP untuk keseluruhan area pada skenario 1 yaitu sebesar $-74,10 \mathrm{dBm}$ dan skenario 2 yaitu sebesar $-74,08$ $\mathrm{dBm}$. Nilai SIR untuk keseluruhan area pada skenario 1 yaitu sebesar 19,04 dB dan skenario 2 yaitu sebesar 21,49 dB. Apabila menggunakan KPI operator acuan yaitu untuk parameter RSRP harus > $-90 \mathrm{dBm}(90 \%$ area) dan parameter SIR harus $>0 \mathrm{~dB}$ (90\% area) maka hasil prediksi disimulasi nilai RSRP dan SIR skenario 1 dan 2 mencapai target KPI. Dari segi nilai parameter RSRP dan SIR juga dari segi untuk memberikan kualitas layanan terbaik di dalam bangunan skenario 2 lebih cocok untuk digunakan.

\section{Daftar Pustaka}

[1] J. Pour, "Dari gelora bung karno ke gelora bung karno (dalam indonesian)," Jakarta: Grasindo, 2012.

[2] C. Christopher, "An introduction to lte 2nd," John Wiley \& Sons, Ltd., West Sussex, 2014.

[3] M. Tolstrup, "Indoor radio planning a practical guide for $2 \mathrm{~g}, 3 \mathrm{~g}$ and $4 \mathrm{~g}$, 3rd edition," West Sussex:WILEY, 2015.

[4] F. N. C. Inc, "High capacity indoor wireless solution: Picocell or femtocell?," Texas:Richardson, 2013.

[5] C. Huawei Technologies., "Radio network capacity dimensioning," Huawei, 2013.

[6] C. Huawei Technologies., "Radio network," Huawei, 2010.

[7] C. Huawei Technologies., "Bandwidth calculation for picocell," Huawei.

[8] U. K. Usman, "Fundamental teknologi seluler lte," Bandung: Rekayasa Sains, 2012.

[9] A. Aziz, "Analisa perencanaan indoor wi-fi ieee 802.11 n pada stadion si jalak harupat," Bandung: Universitas Telkom, 2016. 